\title{
LAYANAN INFORMASI BERBASIS PENGUKURAN PSIKOLOGI UNTUK KEMANTAPAN PEMILIHAN STUDI LANJUT SISWA KELAS XII IPA 5 SMAN 1 BAE KUDUS TAHUN 2014 / 2015
}

\author{
Istiah, S.Pd \\ Istiah2015@gmail.com \\ SMAN 1 Bae Kudus
}

\begin{abstract}
Many students are confused in planning their further studies. Many of them choose a course of study without considering their inner potential. They choose a course of study because of their parent's willingness, or being influenced by their group, close friends and other influences, and rule out the potentials that exist in them. The problem statement of the study is whether the application of psychologi measurement-based information services can increase the motivation stability of the students in choosing their course of study in college. The aims of the study is to improve the information's service quality and increase the motivation stability of students in determining further course of study that facilitate their studies and careers. The research hypothesis is "the information services based on psychologi measurement are effective to increase the motivation stability in selecting further studies of the students of Class XII-Science-5, SMAN 1 Bae Kudus, in the academic year of 2014/2015.

This study is a two cycled action research on guidance and counseling. The research subject is the students of Class XII-Science-5, SMAN 1 Bae Kudus, in the academic year of 2014/2015. The independent variable of the study is information services based on psychologl measurement, while the dependent variable is the selection of course study in college after graduating from Senior High School. The method of data collection is questionnaire, observation, photo and document analysis. The data analysis is descriptive, percentage and qualitative analysis.

The research finding shows that there is $84,37 \%$ improvement of students' motivation stability in determining their further studies and $15,63 \%$ constant. From the observation done by the collaborator, it shows that the students were very enthusiastic in joining the service from the first meeting until the last meeting. The counseling teacher as the researcher presented the material systematically and seriously. She kept developing her competence in giving the information services assisted by the use of multimedia optimally from the $1^{\text {st }}$ meeting until the $4^{\text {th }}$ meeting (last meeting). Referring to Laiseg, it also shows improvement of students' motivation stability gradually shown by the description of the first meeting: $21,87 \%$, second meeting: $37,50 \%$, third meeting: $62,50 \%$, and the fourth meeting: $84,38 \%$.

It is concluded that the information services based on psychologi measurement can make the students feel more motivated in determining their choice for further course studies in college. It is recommended that the related parties need to motivate the students to determine their choice of further studies based on students' talent (aptitude) and interest as well as other potentials.
\end{abstract}


Keywords: Information Services, Psychologi Measurement, and Selecting Further Studies

\begin{abstract}
ABSTRAK
Latar belakang penelitian adalah banyak siswa mengalami kebingungan dalam merencanakan studi lanjut. Banyak yang memilih program studi yang dianggap populer tanpa mempertimbangkan potensi diri, banyak juga yang memilih program studi karena kemauan orang tua, terpengaruh kelompoknya, teman akrab dan pengaruh lainnya, dan mengesampingkan berbagai potensi yang ada pada dirinya.Rumusan masalah : Apakah dengan penerapan layanan informasi berbasis pengukuran psikologi dapat meningkatkan kemantapan siswa dalam memilih program studi di perguruan tinggi ? Tujuan penelitian : Meningkatkan kualitas layanan Informasi tentang program studi pada perguruan tinggi dan. meningkatkan kemantapkan siswa menentukan pemilihan program studi sehingga akan memperlancar studi dan karir mereka dimasa depan. Hipotesa penelitian adalah "Dengan Layanan Informasi Berbasis Pengukuran Psikologi akan Menambah Kemantapan Pemilihan Studi Lanjut Pada Siswa Kelas XII IPA 5 SMAN 1 Bae Kudus Tahun 2014 / 2015. Jenis penelitian ini adalah penelitian tindakan bimbingan dan konseling melalui 2 siklus. Subyek adalah Siswa Kelas XII IPA 5 SMAN 1 Bae Kudus. Variabel bebas dalam penelitian ini adalah layanan informasi berbasis pengukuran psikologi Variabel Terikat dalam penelitian ini adalah Pemilihan Program Studi diperguruan tinggi kelak setelah lulus SMA . Metode pengumpulan data yang digunakan yaitu, Angket, Observasi, Foto dan Analisa dokumen. Analisa data menggunakan analisa data deskriptif, persentase dan analisa kualitatif. Hasil penelitian menunjukkan ada peningkatan Kemantapan siswa dalam menentukan pilihan program studi sebanyak 84,37\% sedangkan yang belum meningkat $15,63 \%$ Dari hasil observasi oleh kolaborator menunjukkan bahwa siswa sangat antusias mengikuti layanan ini mulai dari pertemuan pertama sampai pertemuan terakhir. Guru BK selaku peneliti menunjukkan keseriusan dan menyampaikan materi secara sistimatis serta selalu meningkatkan kemampuan dalam melakukan layanan informasi dengan disertai Penggunaan multi media secara optimal mulai pertemuan 1 sampai dengan pertemuan terakhir atau ke 4 Dari Laiseg juga menunjukkan peningkatan kemantapan siswa secara bertahap, dengan gambaran Pertemuan pertama 21, 87 $\%$, Pertemuan kedua $37.50 \%$, Pertemuan ketiga 62,50 \%, pertemuan keempat $84,38 \% \%$
\end{abstract}

Kata Kunci: Layanan Informasi, Pengukuran Psikologi, dan Pemilhan studi lanjut

\title{
PENDAHULUAN
}

Pendidikan merupakan asset bangsa yang sangat penting, tanpa ada pendidikan bangsa akan mengalami kemunduran atau keterpurukan bahkan dapat menjadi bangsa yang terjajah kembali, karena itu banyak pihak diantaranya stake holder, orang tua/keluarga masyarakat bangsa dan penyelenggara negara sangat peduli terhadap pendidikan berbagai pendekatan dan sistem telah diciptakan, dana yang cukup besar telah difokuskan untuk pendidikan, saat ini negara 
mengalokasikan dana sampai $20 \%$ untuk inventasi pendidikan anak bangsa baik dari APBN maupun APBD,

Dalam dunia pendidikan dikenal pendidikan formal pendidikan non formal dan pendidikan informal, pendidikan formal merupakan salah satu unsur penting dalam dunia pendidikan dan salah satu lembaga pendidikan yang adalah SMA.

Banyak pihak menaruh perhatian besar terhadap pendidikan di SMA, bahkan dewasa ini Pemerintahan Kabupaten khususnya Kabupeten Kudus mencanangkan wajib belajar 12 tahun, artinya siswa harus menyelesaikan atau lulus pendidikan sampai SMA/SMK dan pemerintah bertanggungjawab terhadap hal tersebut

Penyelenggaraan pendidikan di SMA memiliki karakteristik yang berbeda dengan di SMK, Pendidikan di SMK lebih ditekankan untuk persiapan memasuki dunia kerja, sedangkan di SMA dipersiapkan melanjutkan ke jenjang pendidikan yang lebih tinggi. karena itu berbagai upaya dilakukan oleh pihak sekolah termasuk guru bidang studi dan guru Bimbingan Konseling serta pihak terkait lainnya untuk lebih memusatkan perhatian, dalam mempersiapkan kemampuan siswa termasuk didalamnya meningkatkan dan memperluas jaringan dengan lembaga-lembaga pendidikan tinggi demi kesuksesan siswa pada studi lanjutan.

Guru Bimbingan Konseling yang secara langsung bernangani siswa terutama yang mengampu kelas XII juga melakukan berbagai upaya dalam mengantarkan siswa menuju kesuksesan studi lanjut serta kesuksesan dalam meniti karir dimasa mendatang, salah satu upayanya adalah melaksanakan Penelitian Tindakan Bimbingan Konseling yang ada relevansinya dengan upaya meraih sukses dalam studi lanjut dan karir dimasa mendatang.

Salah satu Penelitian Tindakan Bimbingan Konseling yang dilakukan adalah "Layanan Informasi Berbasis Pengukuran Psikologi Untuk Kemantapan Pemilihan Studi Lanjut" alasan pentingnya PTBK ini adalah karena banyak ditemui siswa mengalami kebingungan dalam merencanakan studi lanjut. Banyak yang memilih program studi tanpa mempertimbangkan potensi diri, banyak juga yang memilih program studi karena kemauan orang tua, terpengaruh kelompoknya, teman akrab dan pengaruh lainnya, dan mengesampingkan berbagai potensi yang ada pada dirinya.

\section{KAJIAN TEORI}

\section{Pengertian Layanan Informasi}

Layanan Informasi adalah salah satu jenis layanan yang cukup mudah dilaksanakan dan banyak hal yang bisa dicapai dalam layanan, disamping itu layanan informasi juga memiliki dimensi yang luas.Untuk mengenal lebih lanjut tentang layanan informasi perlu didahului dengan pengertian layanan informasi

Adapun pengertian layanan informasi adalah sebagai berikut

Menurut Wjs Poerwadarminta ( 1976 - 573 ) Layanan berarti tindakan atau perlakuan, sedangkan Informasi menurut Wjs Poerwadarminta (1976-380) berarti penerangan .

Menurut Prayitno \& Erman Amti (2004:259-260) layanan informasi adalah kegiatan memberikan pemahaman kepada individu-individu yang berkepentingan 
tentang berbagai hal yang diperlukan untuk menjalani suatu tugas atau kegiatan, atau untuk menentukan arah suatu tujuan atau rencana yang dikehendaki.

Menurut Budi Purwoko (2008:52) penyajian informasi dalam rangka program bimbingan ialah kegiatan membantu siswa dalam mengenali lingkungannya, terutama tentang kesempatan-kesempatan yang ada didalamnya, yang dapat dimanfaatkan siswa baik untuk masa kini maupun masa yang akan datang. Penyajian informasi itu dimaksudkan untuk memberikan wawasan kepada para siswa sehingga ia dapat menggunakan informasi itu baik untuk mencegah atau mengatasi kesulitan yang dihadapinya, serta untuk merencanakan masa depan. Perencanaan kehidupan ini mencakup, kehidupan dalam studinya, dalam pekerjaannya, maupun dalam membina keluarga.

Sedangkan Winkel \&Sri Hastuti (2006: 316-317) menjelaskan bahwa layanan informasi adalah usaha untuk membekali para siswa dengan pengetahuan tentang data dan fakta dibidang pendidikan sekolah, bidang pekerjaan dan bidang perkembangan pribadi-sosial, supaya mereka dengan belajar tentang lingkungan hidupnya lebih mampu mengatur dan merencanakan kehidupannya sendiri.

Dari beberapa pengertian tentang layanan informasi diatas dapat disimpulkan bahwa layanan informasi adalah suatu kegiatan atau usaha untuk membekali para siswa tentang berbagai macam pengetahuan dibidang pendidikan sekolah, bidang pekerjaan dan bidang perkembangan pribadi-sosial, agar mereka mampu mengatasi kesulitan hidupnya dan dapat mengambil keputusan secara tepat dalam kehidupannya.

Layanan informasi adalah salah satu jenis layanan dalam bimbingan dan konseling, layanan ini cukup efektif digunakan untuk menyampaikan atau mendukung tugas-tugas bimbingan konseling.

Layanan dimaksud adalah layanan informasi tentang strategi memilih studi lanjut, berbagai bentuk perguruan tinggi, program studi, daya tampung, materi yang dipelajari pada masing-masing program studi dan prospek kariernya. Disamping itu juga diperlukan layanan informasi tentang berbagai potensi diri termasuk bakat, minat yang telah tergambar dalam tes psikologi yang sudah dilakukan siswa pada saat kelas $\mathrm{X}$ atau awal masuk SMA, serta aplikasi hasil tes psikologi tersebut untuk pemilihan program studi.

\section{PengertianPengukuran Psikologi.}

Pengukuran psikologi adalah cara atau prosedur untuk memperoleh informasi yang dapat dikuantifikasikan pada suatu tingkah laku yang nampak yang merupakan pencerminan, prestasi, bakat, sikap dan aspek-aspek kepribadian yang lain.

Pengukuran psikologi telah dibakukan dan selalu menggunakan alat yang dinamakan alat tes, adapun pengertian Tes adalah alat pengukur untuk menetapkan apakah berbagai cerminan dari prilaku yang kita perkirakan dari seseorang adalah benar merupakan fakta, juga adalah cara untuk menggambarkan bermacam-macam gejala yang tampak seobyektif mungkin.(Conny Semiawan Stamboel, 1982. P. 24-25).

Dengan alat tes yang telah dibakukan maka hasil dapat dijamin valid dan reliabel sehingga dapat dijadikan sebagai sebagai dasar untuk berbagai kepentingan terutama pemilihan program studi pada perguruan tinggi 


\section{Layanan Informasi Berbasis Pengukuran Psikologi}

Layanan Informasi Berbasis Pengukuran Psikologi adalah salah satu jenis layanan yang diberikan Guru Bimbingan Konseling kepada para siswa, dengan menggunakan hasil pengukuran/tes psikologi yang telah dimiliki siswa sebagai pokok pembahasan

\section{METODE PENELITIAN}

\section{A. Setting Penelitian dan Karakteristik Subjek Penelitian}

\section{Setting Penelitian}

Pelaksanaan Penelitian ini dilakukan pada siswa Kelas XII IPA 5 SMAN 1 Bae Kudus Tahun 2014 / 2015

\section{a). Karakteristik Subyek Penelitian}

Kebanyakan siswa masih idealis, belum memiliki kemantapan dalam menentukan program studi, banyak diantara mereka yang memilih program studi tidak rasional, diantaranya gengsi orang tua, gengsi diri sendiri serta banyak juga yang ikut ikutan teman.

b). Variabel Penelitian.

1)Variabel Bebas atau Variabel $X$ (independent Variabel)

Variabel bebas penelitian ini adalah layanan informasi berbasis pengukuran psikologi

2) Variabel Terikat atau Variabel Y (Dependent Variabel)

Variabel terikat penelitian ini adalah Pemilihan Program Studi diperguruan tinggi kelak setelah lulus SMA .

\section{Rancangan Penelitian Tindakan Kelas}

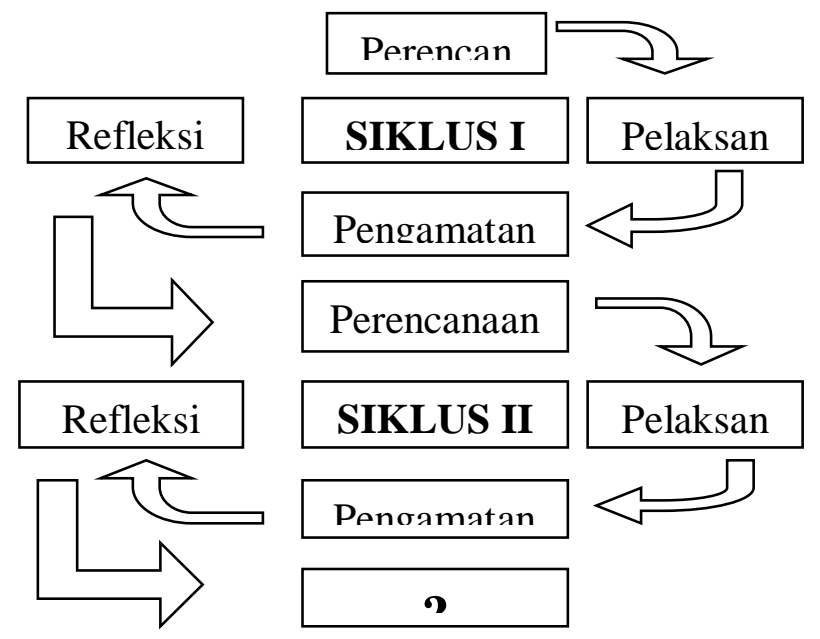

Gambar 3.1Skema Siklus Penelitian Tindakan Kelas

(Sumber: Arikunto, Suhardjono, Supardi, 2008:16)

\section{Prosedur Penelitian}

Urutan langkah-langkah penelitian tindakan bimbingan konseling ini secara rinci dapat digambarkan sebagai berikut : 


\begin{tabular}{|c|c|c|c|c|}
\hline $\mathrm{No}$ & Siklus & Pertemuan & Materi & Waktu \\
\hline 1 & & Pertemuan 1 & $\begin{array}{l}\text { Strategi memilih studi } \\
\text { lanjut di Perguruan } \\
\text { Tinggi }\end{array}$ & 45 Menit \\
\hline 2 & Siklus I & Pertemuan 2 & $\begin{array}{l}\text { Berbagai Perguruan } \\
\text { Tinggi, Program Studi, } \\
\text { Daya Tampung dan Hal- } \\
\text { hal yang dipelajari serta } \\
\text { Prospeknya }\end{array}$ & $2 \times 45$ Menit \\
\hline 3 & & Pertemuan 3 & $\begin{array}{l}\text { Tes psikologi, Aspek- } \\
\text { aspek yang diungkap dan } \\
\text { Manfaatnya }\end{array}$ & 45 Menit \\
\hline 4 & Siklus II & Pertemuan 4 & $\begin{array}{l}\text { Aplikasi Hasil tes } \\
\text { Psikologi untuk } \\
\text { Pemilihan Program studi } \\
\text { pada Perguruan Tinggi } \\
\text { dan Tayangan video } \\
\text { terkait tentang pemilihan } \\
\text { jurusan }\end{array}$ & $2 \times 45$ Menit \\
\hline 5 & $\begin{array}{l}\text { Kegiatan } \\
\text { lanjutan bila } \\
\text { diperlukan }\end{array}$ & Pertemuan 5 & $\begin{array}{l}\text { Memberikan layanan } \\
\text { konseling individual }\end{array}$ & $\begin{array}{l}\text { Sesuai } \\
\text { kesepakatan } \\
\text { antara } \\
\text { konselor dan } \\
\text { konseli }\end{array}$ \\
\hline
\end{tabular}

\section{Metode Pengumpulan Data}

Metode yang digunakan dalam penelitian ini adalah sebagai berikut :

a. Metode Observasi

b. Metode Angket.

c. Metode Wawancara.

d. Foto dan Analisis dokumen

\section{HASIL PENELITIAN DAN PEMBAHASAN}

1. Kondisi Awal

Ada kecenderungan sebagian besar siswa mengalami kebingungan dan kegamangan dalam merencanakan studi lanjut. Banyak diantara siswa yang memilih program studi yang dianggap populer/favorit Banyak juga diantara siswa yang memilih program studi karena kemauan orang tua, terpengaruh atau ikut-ikutan kelompoknya, teman akrab, pacar, memilih perguruan tinggi almamater orang tuanya atau saudara dekatnya, atau almamater guru yang mengarahkan atau guru yang dekat, memilih perguruan tinggi yang dekat dengan tempat tinggal atau kuliah asal asalan yang penting kuliah dengan mengesampingkan potensi dasar yang ada pada dirinya. berikut:

Dari pelaksanaan Siklus I dan Siklus II dapat diperoleh temuan sebagai 
Dengan membandingkan antara hasil angket penjajagan pilihan program studi tahap I yang berfungsi sebagai pre test dan angket penjajagan program studi tahap II yang berfungsi sebagai post test dapat diperoleh gambaran sebagai berikut :

Jumlah Renponden 32 Yang meningkat Kemantapan pemilihan program studi 27 Responden atau $=84,37 \%$ ini berarti sebagian besar siswa mengalami peningkatan Kemantapan pemilihan program studi pada Perguruan Tinggi melebihi target yang ditetapkan yaitu $70 \%$, sedangkan

Yang tidak meningkat 5 Responden atau 15,63\%

Akumulasi Hasil Angket Penjajagan Pemilihan Program Studi Tahap I dan II

\begin{tabular}{|c|c|c|c|c|c|c|}
\hline No & Interval & Frekuwensi & $\boldsymbol{\%}$ & Frekuensi & $\%$ & Kategori \\
\hline 1 & $62-68$ & 5 & 15,62 & 1 & 3,12 & Rendah \\
\hline 2 & $69-75$ & 26 & 81,25 & 7 & 21,87 & Sedang \\
\hline 3 & $76-82$ & 1 & 3,12 & 18 & 56,25 & Tinggi \\
\hline 4 & $83-89$ & 0 & 0 & 6 & 18,75 & $\begin{array}{c}\text { SangatTingg } \\
\text { i }\end{array}$ \\
\hline
\end{tabular}

Grafik Perbandingan Hasil Angket Penjajagan Pemilihan Program Studi Tahap I dan II

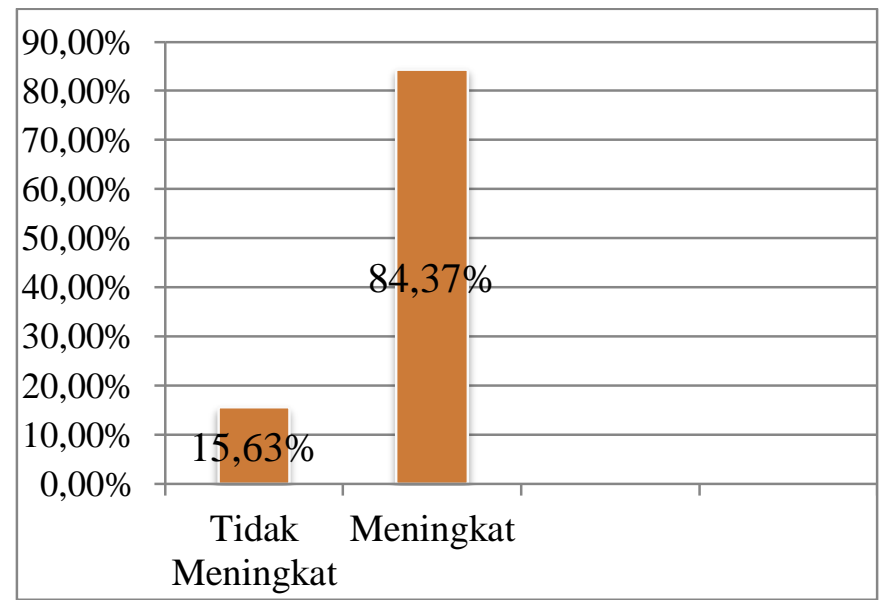

Dari tindakan Siklus I dan Siklus II yang masing-masing diselenggarakan dalam dua kali pertemuan diperoleh data dengan tabel sebagai berikut

\begin{tabular}{|c|c|c|c|}
\hline No & $\begin{array}{c}\text { Pertemuan } \\
\text { Ke }\end{array}$ & $\begin{array}{c}\text { Yang telah Mantap } \\
\text { memilih program studi }\end{array}$ & $\begin{array}{c}\text { Persentase } \\
\%\end{array}$ \\
\hline 1 & 1 & 7 & 21,875 \\
\hline 2 & 2 & 12 & 37.5 \\
\hline 3 & 3 & 20 & 62.5 \\
\hline 4 & 4 & 27 & 84.375 \\
\hline
\end{tabular}


Hasil pengumpulan data yang dihimpun dari siswa selama empat kali pertemuan dengan menggunakan laiseg dapat disajikan Grafik Perkembangan Kemantapan Pilihan Program Studi sebagai berikut:

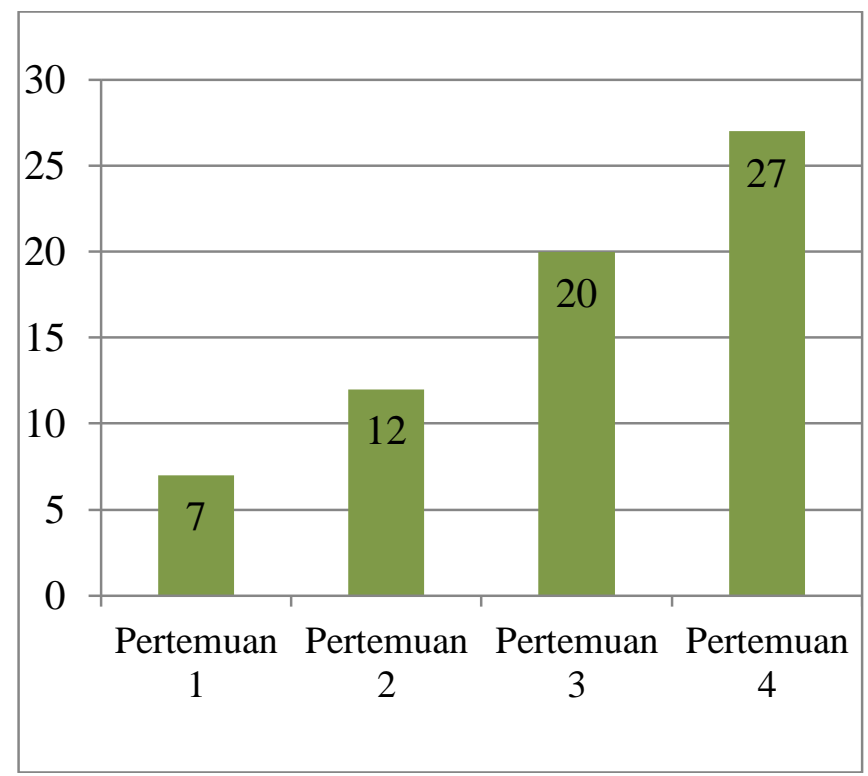

Grafik Persentase Perkembangan Kemantapan Pilihan Program Studi dari Laiseg

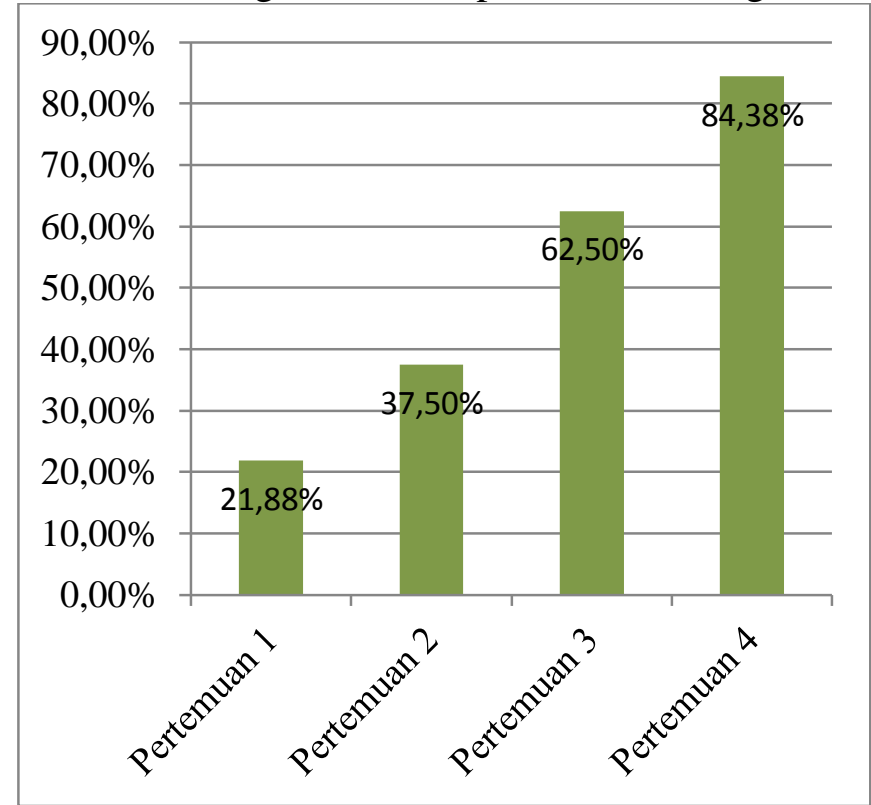

Tabel Kesesuaian Antara Bakat, Minat, Inventory dengan Pilihan Program Studi

\begin{tabular}{|c|c|c|c|c|}
\hline \multirow{2}{*}{ Jenis Alat Ungkap } & \multicolumn{2}{|c|}{ Program Studi } & \multicolumn{2}{c|}{ Persentase } \\
\cline { 2 - 5 } & Sesuai & Tidak Sesuai & Sesuai & Tidak Sesuai \\
\hline Bakat & 24 & 8 & 75 & 25 \\
\hline Minat & 30 & 2 & 93,75 & 6,25 \\
\hline Inventory Minat & 28 & 4 & 87,50 & 12,25 \\
\hline
\end{tabular}




\section{Pembahasan}

Dengan melihat hasil penelitian yang dihimpun dari siswa melalui laiseg selama empat kali peratemuan dan data dari angket penjajagan mulai dari kondisi awal, siklus I dan II terlihat adanya proses perkembangan peningkatan berbagai aspek antara lain sebagai berikut :

Setelah mendapatkan layanan Informasi Berbasis Pengukuran Psikologi siswa menjadi lebih mantap dalam menentukan pilihan program studi dan sebagian besar siswa telah menentukan pilihan dengan mendasarkan pada bakat dan minat sebagaimana hasil pengukuran psikologi yang telah diikuti siswa. Hal ini disebabkan karena guru telah menerangkan secara mendetail dan menyeluruh juga disertai contoh-contoh sehingga siswa benar-benar dapat mengaplikasikan dalam menentukan pilihan program studi . Hal ini sesuai dengan penelitian yang dilakukan oleh Dwi Dessy Setyowati dan Mochamad Nursalim ( 2009 ) yang berjudul "Pengaruh Layanan Informasi Studi Lanjut Terhadap Kemantapan Pengambilan Keputusan Studi Lanjut”. Yang hasilnya ; ada pengaruh positif dengan pemberian layanan informasi studi lanjut terhadap kemantapan pengambilan keputusan studi lanjut siswa. Kemantapan siswa dalam memilih program studi bisa juga ditingkatkan dengan layanan bimbingan kelompok yang efektif, hal ini sesuai dengan penelitian yang dilakukan oleh Dinar Mahdalena Leksana ( 2011) yang berjudul Keefektifan Penerapan Bimbingan Kelompok Untuk Meningkatkan Pemahaman Program Penjurusan Siswa. Yang hasilnya, bimbingan kelompok dengan topik tugas efektif digunakan untuk meningkatkan pemahaman pemilihan program penjurusan.

Keberhasilan itu juga disebabkan karena adanya faktor penunjang yaitu penyampaian materi dengan multi media

Bahwa keberhasilan siswa juga mengindikasikan keberhasilan guru dalam memberikan layanan, keberhasilan guru itu karena adanya mempersiapkan penelitian tindakan kelas dengan perencanaan yang cukup matang meliputi penyiapan materi yang sangat dibutuhkan siswa diantaranya; Strategi Memilih Studi Lanjut, Berbagai Perguruan Tinggi, Program Studi dan Daya Tampung, Materi yang dipelajari pada Masingmasing Program Studi dan Prospeknya, Tes Psikologi, Aspek yang diungkap dan Manfaatnya serta Aplikasi Hasil Tes Psikologi untuk Pemilihan Program Studi pada Perguruan Tinggi juga ditunjang dengan multi media dan ketersediaan waktu yang mencukupi, bagi siswa yang belum mencapai hasil yang diharapkan atau belum bisa menentukan pilihan studi lanjut sebagaimana mestinya maka akan diberi perlakuan khusus yaitu dengan diberikan layanan konsultasi atau layanan konseling, ini dimaksudkan agar tidak mengganggu aktifitas teman, dan guru bisa memantau serta menjajagi perkembangan siswa terkait pemilihan Studi lanjut pada perguruan tinggi. 


\section{KESIMPULAN}

1. Dari hasil penelitian menunjukkan ada peningkatan Kemantapan siswa dalam menentukan pilihan program studi sebanyak 84,37\% sedangkan yang belum meningkat $15,63 \%$

2. Dari hasil observasi oleh kolaborator menunjukkan bahwa siswa sangat antusias mengikuti layanan ini mulai pertemuan pertama sampai pertemuan terakhir. Guru BK selaku peneliti menunjukkan keseriusan dan sistimatis dalam menyampaikan materi serta selalu meningkatkan kemampuan dalam memberikan layanan informasi disertai Penggunaan multi media mulai pertemuan 1 sampai pertemuan terakhir atau ke 4

3. Dari Laiseg juga menunjukkan peningkatan kemantapan siswa secara bertahap, dengan gambaran Pertemuan pertama $21,87 \%$, Pertemuan kedua $37.50 \%$, Pertemuan ketiga $62,50 \%$, pertemuan keempat $84,38 \%$

4. Dengan layanan informasi berbasis Pengukuran Psikologi menjadikan siswa semakin mantap dalam menentukan pilihan Program Studi pada Perguruan Tinggi

\section{SARAN}

Berdasarkan hasil penelitian di atas maka dapat diajukan saran-saran sebagai berikut:

1. Kepada Peneliti Berikutnya.

Apabila akan meneliti hal sejenis disarankan untuk memberikan perhatian serius pada materi dan bersifat menyeluruh serta mengembangkan penelitian ini pada aspek lain secara lebih detail sebagai tindak lanjut dari hasil penelitian ini.

2. Kepada Guru Bimbingan dan Konseling

Hasil penelitian ini hendaknya dipakai sebagai referensi untuk memberikan layanan penempatan dan penyaluran atau layanan lain yang relevan

3. Bagi Sekolah

Agar mempublikasikan hasil penelitian ini sehingga dapat menambah pengetahuan bagi personil sekolah

4. Bagi Guru Bidang Studi

Hendaknya menggunakan hasil penelitian ini untuk memberi motivasi pada para siswa agar selalu pengembangkan potensi yang dimiliki dalam merencanakan masa depannya.

\section{DAFTAR PUSTAKA}

Arikunto, Suhardjono dan Supardi. 2008. Penelitian Tindakan Kelas. Jakarta: Bumi Aksara.

Conny Semiawan Stamboel, 1982, Prinsip dan Teknik pengukuran dan penilaian di dalam dunia pendidikan, Jakarta; Mutiara p.20-26

Prayitno \& Amti, Erman. (2004). Dasar-Dasar BK. Jakarta: Rineka Cipta. 
Purwoko, Budi. (2008) Organisasi dan Managemen Bimbingan Konseling. Surabaya: Unesa University Press.

Winkel \& Hastuti, Sri. (2006). Bimbingan Dan Konseling Di Institusi Pendidikan. Yogjakarta: Media Abadi.

Wjs Poerwadarminta,(2006), Kamus Umum Bahasa Indonesia, Jakarta, Penerbit PN Balai Pustaka 